\title{
Individual responses of trace-element assimilation and physiological turnover by the marine copepod Calanus sinicus to changes in food quantity
}

\author{
Yan Xu, Wen-Xiong Wang* \\ Department of Biology, The Hong Kong University of Science and Technology (HKUST), Clear Water Bay, Kowloon, \\ Hong Kong, PR China
}

\begin{abstract}
The assimilation efficiencies (AEs) of 3 trace elements (Cd, Se, and Zn) from ingested algal food (the diatom Thalassiosira weissflogii and the dinoflagellate Prorocentrum minimum) in individuals of the marine copepod Calanus sinicus were measured. In general, the metal AEs were comparable in copepods feeding on $T$. weissflogii and P. minimum. They decreased by 1.4 to $2.0 \times, 1.2$ to $1.5 \times$ and 2.2 to $2.7 \times$ for $\mathrm{Cd}$, Se, and $\mathrm{Zn}$, respectively, after a $20 \times$ increase in food concentration (0.054 to $1.076 \mathrm{mg} \mathrm{C}^{-1}$ for $T$. weissflogii, 0.174 to $3.470 \mathrm{mg} \mathrm{C}^{-1}$ for $P$. minimum). The physiological turnover-rate constant was, however, independent of food density. There was no evidence of any effect of starvation on metal AEs. The AE of $\mathrm{Cd}$ in the copepods was significantly correlated with its distribution in the algal cytoplasm, whereas no such relationship was found for Se and Zn. This study also indicated that the metal AEs were positively related to the gut transit-time of food particles and the gut passage-time of metals in the copepods, implying a more efficient digestion and absorption when the food particles and metals were retained longer in the digestive tract. The gut physiology of copepods may thus considerably affect metal assimilation in diverse food environments. Most unassimilated $\mathrm{Cd}$ and $\mathrm{Zn}$ was lost by copepods through feces egestion, whereas excretion contributed substantially to the loss of unassimilated Se from the copepods. Excretion was a major route by which assimilated metals were depurated and turned over from the copepods. The relative contribution of fecal egestion to the total metal loss from copepods increased with increasing food concentration. Physiological responses of metal uptake by marine copepods in response to phytoplankton blooms may thus influence the fate of metals in aquatic systems.
\end{abstract}

KEY WORDS: Calanus sinicus $\cdot$ Assimilation efficiency $\cdot$ Gut passage-time $\cdot$ Cadmium Selenium $\cdot$ Zinc

\section{INTRODUCTION}

Marine copepods are the most abundant zooplankton in pelagic waters, and play an important role in the biogeochemical cycling of carbon and trace metals in marine ecosystems. Zooplankton grazing can strongly influence the fate of carbon and trace metals associated with phytoplankton biomass (Fowler \& Knauer 1986). During grazing, metals which are assimilated into grazer biomass enter the organic cycling in the sea, and may have longer residence times in the sur-

${ }^{*}$ Corresponding author. E-mail: wwang@ust.hk face waters (Whitfield \& Turner 1987, Fisher et al. 1991, Reinfelder \& Fisher 1991). Metals that are egested with sinking fecal pellets will be exported out of the surface waters (Fowler \& Knauer 1986), enriching the deep-water dissolved-metal pool through remineralization and release (Fisher et al. 1991, Lee \& Fisher 1992). Cellular metals regenerated in the dissolved state during grazing may be recycled many times and re-utilized by the phytoplankton community (Hutchins et al. 1993, Hutchins \& Bruland 1994, Lee \& Fisher 1994, Wang \& Fisher 1998a,b). The relative importance of these different biogeochemical pathways is metal-specific and can vary greatly with graz- 
ing conditions (Hutchins et al. 1995). Information on the uptake, assimilation, egestion, and regeneration of carbon and trace elements is therefore important in evaluating the processes regulating the biogeochemical fate of these elements in the ocean.

Several recent studies have measured the assimilation efficiencies (AEs) of trace metals from ingested phytoplankton in marine copepods (Fisher et al. 1991, Reinfelder \& Fisher 1991, Hutchins et al. 1995, Wang et al. 1996, Wang \& Fisher 1998a). A few studies have demonstrated that the assimilation of trace elements is governed by cytoplasmic distribution in prey cells (Reinfelder \& Fisher 1991, Hutchins et al. 1995). This 'liquid' digestive strategy may allow marine copepods to process ingested food materials rapidly and minimize their energy expenditure (Kiørboe et al. 1985, Wang et al. 1996). Physiological control of metal assimilation by marine copepods has generally been assumed to be minimal, but this remains essentially untested; for example, it is not known whether the gut passage-time of metals in copepods can influence metal assimilation. In marine bivalves, it has been shown that the AEs of trace elements are highly dependent on gut passage-time (Decho \& Luoma 1991, Wang et al. 1995, Wang \& Fisher 1996), presumably because longer retention may enable food materials to be more thoroughly digested and efficiently absorbed by animals with both extracellular and intracellular digestive strategies (Wang \& Fisher 1996).

The rates and routes of trace-metal release from biogenic particles into the dissolved state have also been quantified for zooplankton debris (Lee \& Fisher 1992, 1994, Reinfelder et al. 1993, Wang et al. 1996, Wang \& Fisher 1998a). There are, however, relatively few studies on the routes of trace-metal loss from marine copepods after ingestion of particulate metals (Hutchins et al. 1995, Wang et al. 1996, Schmidt et al. 1999). Although these previous studies suggested that metal regeneration by copepod grazing contributed substantially to the dissolved-metal pool, no study has quantitatively compared the relative importance of egestion versus excretion in the overall metal loss from copepods, including both unassimilated and assimilated metals. The biogeochemical fates of egested and excreted metals are not yet fully understood. It is generally difficult to separate completely excretion from egestion of metals in experimental studies because of the difficulty of fully recovering metals associated with fecal material. To address this difficulty, fecal material would have to be removed immediately after egestion by the copepods, thus avoiding recycling of the lost metal into the aqueous phase. With this method, it is possible to assess quantitatively metal loss from fecal pellet egestion or excretion into the dissolved phase.
Calanus sinicus is one of the dominant zooplankton species in Chinese coastal waters, and plays an important role in marine ecosystem dynamics in the region. The relatively large size of the adults of this species (1 to $2 \mathrm{~mm}$ in length) enable its metal assimilation responses to changes in its food environment to be examined on an individual basis. Although previous studies have quantified the metal AE and physiological turnover rate in a few species of marine copepods (e.g., Acartia sp., Temora longicornis), none has measured the assimilation and physiological turnover of metals for individual copepods. In this study, we examine the effects of food concentration, algal diet species, and the physiological condition of the copepods (starvation) on the AEs and the physiological turnover rates of $\mathrm{Cd}, \mathrm{Se}$, and Zn. Two phytoplankton species, Thalassiosira weissflogii and Prorocentrum minimum, were examined. The loss of unassimilated and assimilated metals through egestion or excretion was quantitatively evaluated in various food environments for individual copepods.

\section{MATERIALS AND METHODS}

Adult female Calanus sinicus were collected by nettowing (500 $\mu \mathrm{m}$ nylon mesh) from Port Shelter, Clear Water Bay, Hong Kong. The copepods were maintained in the laboratory in 30 psu glass-fiber-filtered (GFF) seawater and fed with the algal food. All experiments were carried out at 20 to $22^{\circ} \mathrm{C}$ and $30 \mathrm{psu}$.

Radiolabeling of phytoplankton. Two species of phytoplankton, Thalassiosira weissflogii (CCMP 1048) and Prorocentrum minimum (CCMP 696), were maintained in clonal cultures in $\mathrm{f} / 2$ medium (Guillard \& Ryther 1962) at $18^{\circ} \mathrm{C}$ with a illumination of $100 \mu \mathrm{E} \mathrm{m} \mathrm{m}^{-2}$ $\mathrm{s}^{-1}$ on a 14:10 h light:dark cycle. Cells in late log-stage were collected onto a $3 \mu \mathrm{m}$ polycarbonate membrane and resuspended in $50 \mathrm{ml} 0.2 \mu \mathrm{m}$-filtered seawater enriched with f/2 levels of $\mathrm{N}, \mathrm{P}, \mathrm{Si}$ (for $T$. weissflogii only), and vitamins, and f/20 levels of trace metals without addition of $\mathrm{Cu}, \mathrm{Zn}$, and EDTA. The initial cell concentration in the media was generally $2 \times 10^{4}$ cells $\mathrm{ml}^{-1}$. The amounts of radioisotope additions were $37 \mathrm{kBq}$ of ${ }^{109} \mathrm{Cd}$ (in $0.1 \mathrm{~N} \mathrm{HCl}$, corresponding to $89 \mathrm{nM}$ ), $55.5 \mathrm{kBq}$ of ${ }^{75} \mathrm{Se}(\mathrm{IV})$ (in distilled water, corresponding to $1.8 \mathrm{nM}$ ), and $74 \mathrm{kBq}$ of ${ }^{65} \mathrm{Zn}$ (in $0.1 \mathrm{~N} \mathrm{HCl}$, corresponding to $2.1 \mathrm{nM}$ ). The $\mathrm{pH}$ of the seawater was adjusted to 8.0 by adding $0.5 \mathrm{~N}$ Suprapur $\mathrm{NaOH}$.

After 4 to 5 d growth for Thalassiosira weissflogii, or 7 d growth for Prorocentrum minimum, cell densities reached 1 to $2 \times 10^{5}$ cells ml ${ }^{-1}$ ( 3 to 4 divisions) and were considered to be uniformly radiolabeled. Cells were then collected by filtration onto $3 \mu \mathrm{m}$ polycarbonate membranes and resuspended in $0.2 \mu \mathrm{m}$ filtered unla- 
beled seawater. Cell density was counted before the cells were fed to the copepods. The distribution of radioisotopes in various cellular fractions was determined by differential centrifugation, as described in Fisher et al. (1983) and Reinfelder \& Fisher (1991). Briefly, the weakly-bound surface metals were removed by $0.1 \mathrm{mM}$ EDTA. The cells were then suspended in distilled water and frozen. They were later thawed and centrifuged at $2000 \times g(15 \mathrm{~min})$ and $20000 \times g(20 \mathrm{~min})$ sequentially. The supernatant after $20000 \times g$ centrifugation was defined as the cytosolic fraction.

Assimilation and physiological turnover of metals by copepods. Before the assimilation experiments, copepods were allowed to evacuate their guts for $1 \mathrm{~h}$ without the presence of food particles. Individual female copepods were then added to well dishes, each containing 1 individual copepod and $10 \mathrm{ml}$ GFF seawater. There were 6 replicate individuals for each experimental treatment. The radiolabeled algal cells were then added to the $10 \mathrm{ml}$ GFF seawater at different concentrations. After feeding on the radiolabeled food particles for various lengths of time (from 10 to 60 min: see below), the copepods were removed, rinsed with filtered seawater and immediately placed in $2 \mathrm{ml}$ filtered seawater. The radioactivity of the copepods was immediately counted, and they were returned to $10 \mathrm{ml}$ of filtered nonradioactive seawater to depurate their ingested radiolabeled food materials for $12 \mathrm{~h}$, under the same conditions and in the presence of nonradioactive food. Any fecal pellets egested during the radioactive feeding and depuration periods were also immediately removed, rinsed with filtered seawater, and assayed for radioactivity. The total amount of radioactivity ingested by the copepods during the radioactive feeding period was calculated as the sum of the radioactivity detected in the copepods and in the produced feces. The radioactivity in the copepods was measured every 1 to $4 \mathrm{~h}$ over the $12 \mathrm{~h}$ depuration period. The seawater and food were replaced each time radioactivity in the copepods was counted. The original seawater was then counted for radioactivity.

In food-quantity experiments with Prorocentrum minimum and Thalassiosira weissflogii, 3 cell concentration treatments were prepared: $2 \times 10^{3}, 8 \times 10^{3}$, and $4 \times 10^{4}$ cells ml $^{-1}$ (equivalent to $0.054,0.215$, and $1.076 \mathrm{mg} \mathrm{Cl}^{-1}$ for $T$. weissflogii, and $0.174,0.694$, and $3.470 \mathrm{mg} \mathrm{Cl}^{-1}$ for P. minimum). The copepods were fed with the radioactive food particles for $20 \mathrm{~min}$. In the experiment examining the influences of different radioactive pulse-feeding durations on metal assimilation, the copepods were fed with $T$. weissflogii at a concentration of $4 \times 10^{4}$ cells ml ${ }^{-1}$ for 10,30 , and $60 \mathrm{~min}$, respectively. In the experiment examining the effects of the physiological condition of copepods on metal assimilation, the copepods were starved for $18 \mathrm{~h}$, and then fed with the radiolabelled $T$. weissflogii for $20 \mathrm{~min}$ at a concentration of $4 \times 10^{4} \mathrm{cells} \mathrm{ml}^{-1}$. The 'control' copepods were fed continuously with diatoms before the experiments.

Ingestion rate and gut transit-time of food particles. To quantify the ingestion rate of copepods feeding on algal cells at different algal concentrations, Thalassiosira weissflogii and Prorocentrum minimum were grown under the same conditions as used for radiolabeling. The cells were collected onto $3 \mu \mathrm{m}$ polycarbonate membranes and resuspended into filtered seawater. Individual copepods were added to the deep-well dishes containing $10 \mathrm{ml}$ of GFF seawater. There were 6 replicate individual copepods to each treatment. The copepods were allowed to feed on the cells in the dark for $1 \mathrm{~h}$. Density before and after feeding was calculated with a Coulter counter. Ingestion rate $(I R, \mu \mathrm{g}$ carbon copepod $^{-1} \mathrm{~h}^{-1}$ ) was calculated by the following equation (Omori \& Ikeda 1992):

$$
I R=W V\left(C_{0}-C_{\mathrm{t}}\right) / t
$$

where $W$ is the carbon dry weight of the cell $(\mu \mathrm{g}), V$ is the volume of seawater $(\mathrm{ml}), C_{0}$ and $C_{\mathrm{t}}$ are the concentrations of algal cells before and after feeding (cells $\mathrm{ml}^{-1}$ ), respectively, and $t$ is feeding period (h). There was a decrease in cell density of about 10 to $20 \%$ after $1 \mathrm{~h}$ feeding at different food concentrations.

The time required for the copepods to produce their first feces was also examined at different food concentrations. Copepods were first allowed to evacuate their gut contents for $1 \mathrm{~h}$ in the absence of food particles. Individual copepods were then added to separate well dishes, each containing $10 \mathrm{ml}$ of GFF seawater and various concentrations of diatoms or dinoflagellates. Any feces produced by the copepods were checked under a microscope every 2 min following the addition of copepods to the dishes. The time required for the first appearance of feces was defined as the gut transittime of food particles (FPT).

Radioactivity measurements. Radioactivity was measured with a Wallac $1480 \mathrm{NaI}(\mathrm{Tl})$ gamma detector. All measurements were related to appropriate standards and calibrated with spillover. The gamma emission of ${ }^{109} \mathrm{Cd}$ was determined as $22 \mathrm{keV}$, of ${ }^{75} \mathrm{Se}$ as $264 \mathrm{keV}$, and of ${ }^{65} \mathrm{Zn}$ as $1115 \mathrm{keV}$. Counting times were adjusted to yield a propagated counting error of $<5 \%$.

\section{RESULTS}

\section{Trace-metal assimilation from ingested food particles}

The retention of $\mathrm{Cd}, \mathrm{Se}$, and $\mathrm{Zn}$ in individuals of Calanus sinicus following a radioactive pulse-feeding 


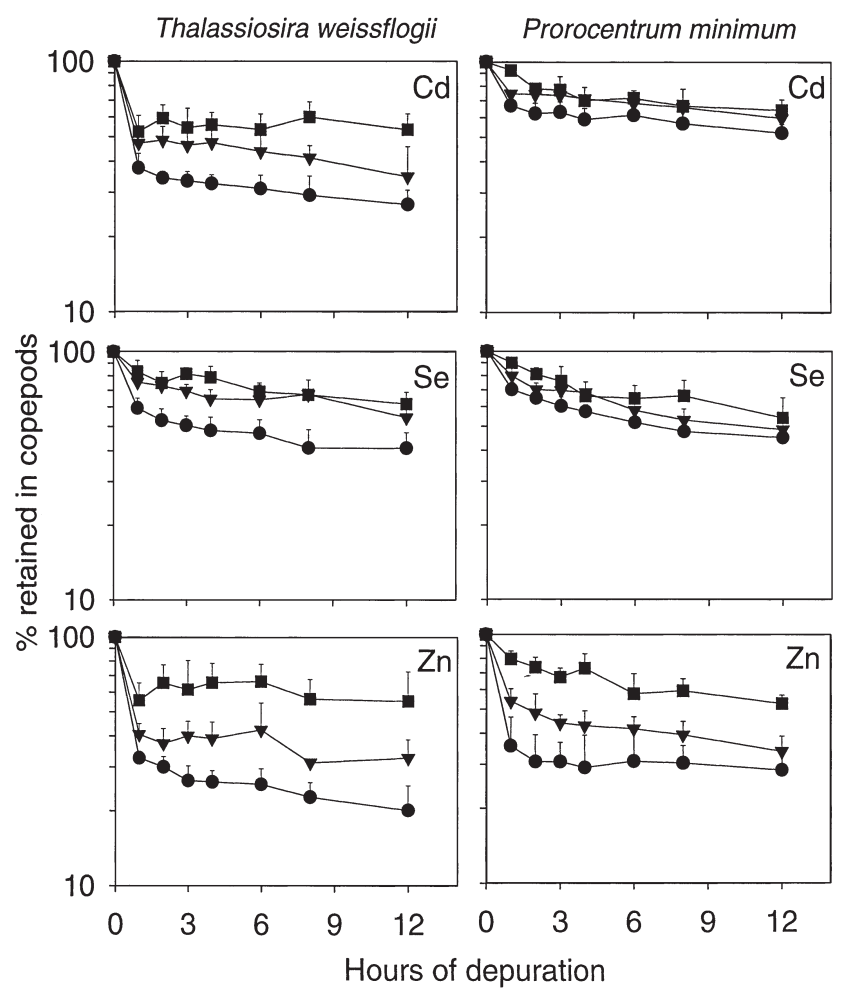

Fig. 1. Calanus sinicus. Retention of $\mathrm{Cd}$, Se, and $\mathrm{Zn}$ following pulse ingestion of the radiolabeled diatom Thalassiosira weissflogii and the dinoflagellate Prorocentrum minimum at different food concentrations. (匹) 2000 cells $\mathrm{ml}^{-1} ;$ ( $\left.\mathbf{\nabla}\right) 8000$ cells $\mathrm{ml}^{-1} ;(\bullet) 40000$ cells ml ${ }^{-1}$. Data are means $+\mathrm{SD}(\mathrm{n}=6)$ is shown in Figs $1 \& 2$. Depuration of the ingested radioactive food particles resulted in a rapid loss within the first $2 \mathrm{~h}$, followed by a gradual loss. No major difference in the depuration pattern was observed among different metals or different treatments. AE was calculated as the $y$-intercept of the regression between the natural log of the percentage of metals retained in the copepods and the time of depuration between 4 and $12 \mathrm{~h}$ (Wang \& Fisher 1999). Because there was negligible loss of metals through fecal egestion after $6 \mathrm{~h}$ depuration, the gut passage-time (GPT) of each metal was defined as the time at which $90 \%$ of egested metal was recovered in the cumulative feces, assuming a 100\% recovery at 6 h depuration (Wang \& Fisher 1999).

The calculated metal AEs for the copepods are shown in Table 1. Differences in food concentration significantly affected the assimilation of $\mathrm{Cd}, \mathrm{Se}$, and Zn. For all 3 metals, AEs decreased significantly with increasing food concentration from $2 \times 10^{3}$ to $4 \times$ $10^{4}$ cells $\mathrm{ml}^{-1}$ ( $\mathrm{p}<0.05,1$-way ANOVA), except for Se in copepods feeding on $P$. minimum. The AEs of $\mathrm{Zn}$ appeared to be most affected by a change in food concentration; for example, its AE decreased by 2.2 to $2.7 \times$ after a $20 \times$ increase in food concentration. Metal AEs were comparable between the 2 different algal diets. AEs of the 3 metals were fairly comparable at the lowest food concentration; at higher algal concentrations, the AEs of Se were higher than those of $\mathrm{Cd}$ and $\mathrm{Zn}$. Differences in the radioactive feeding period (10 to $60 \mathrm{~min}$ ) had little influence on the assimilation of $\mathrm{Cd}$ and $\mathrm{Zn}$, but a relatively higher $\mathrm{AE}$

Table 1. Calanus sinicus. Assimilation efficiencies (AE) and physiological turnover-rate constants $(K)$ of $\mathrm{Cd}$, Se, and $\mathrm{Zn}$ in copepods feeding on the diatom Thalassiosira weissflogii and the dinoflagellate Prorocentrum minimum at different food concentrations (calculated from Figs $1 \& 2$ ). AEs and $K$ of copepods with different radioactive feeding durations and of starved and fed copepods are also shown. Values are means $\pm \mathrm{SD}(\mathrm{n}=6)$. Statistically significant effects of different treatments are indicated by ${ }^{*} \mathrm{p}<0.05,{ }^{* *} \mathrm{p}<0.01$, and ${ }^{* * *} \mathrm{p}<0.0011$-way ANOVA

\begin{tabular}{|c|c|c|c|c|c|c|}
\hline \multirow[t]{2}{*}{ Food type } & \multicolumn{3}{|c|}{$\mathrm{AE}(\%)$} & \multicolumn{3}{|c|}{$K\left(\mathrm{~d}^{-1}\right)$} \\
\hline & $\mathrm{Cd}$ & $\mathrm{Se}$ & $\mathrm{Zn}$ & $\mathrm{Cd}$ & $\mathrm{Se}$ & $\mathrm{Zn}$ \\
\hline \multicolumn{7}{|c|}{ T. weissflogii (food conc.) } \\
\hline $2 \times 10^{3}$ cells ml -1 & $67.9 \pm 12.2^{* *}$ & $81.2 \pm 7.4^{* *}$ & $79.0 \pm 11.3^{* * *}$ & $0.39 \pm 0.11$ & $0.63 \pm 0.14$ & $0.49 \pm 0.21$ \\
\hline $8 \times 10^{3}$ cells ml $\mathrm{ml}^{-1}$ & $53.3 \pm 7.0^{* *}$ & $71.0 \pm 6.6^{* *}$ & $44.0 \pm 11.1^{* * *}$ & $0.61 \pm 0.14$ & $0.66 \pm 0.16$ & $1.15 \pm 0.50$ \\
\hline $4 \times 10^{4}$ cells ml $\mathrm{ml}^{-1}$ & $34.5 \pm 3.0^{* *}$ & $55.6 \pm 5.8^{* *}$ & $29.6 \pm 4.4^{* * *}$ & $0.68 \pm 0.19$ & $0.64 \pm 0.43$ & $0.59 \pm 0.18$ \\
\hline \multicolumn{7}{|c|}{ P. minimum (food conc.) } \\
\hline $2 \times 10^{3}$ cells ml ${ }^{-1}$ & $79.3 \pm 4.5^{* *}$ & $72.5 \pm 6.9$ & $69.7 \pm 10.2^{* *}$ & $0.57 \pm 0.18$ & $0.35 \pm 0.12$ & $0.78 \pm 0.20$ \\
\hline $8 \times 10^{3}$ cells ml $\mathrm{ml}^{-1}$ & $76.0 \pm 3.7^{* *}$ & $66.4 \pm 8.2$ & $47.3 \pm 4.7^{* *}$ & $0.66 \pm 0.20$ & $0.63 \pm 0.24$ & $0.64 \pm 0.24$ \\
\hline $4 \times 10^{4}$ cells ml $\mathrm{ml}^{-1}$ & $57.2 \pm 11.2^{* *}$ & $61.7 \pm 3.6$ & $31.0 \pm 12.3^{* *}$ & $0.50 \pm 0.21$ & $0.61 \pm 0.14$ & $0.74 \pm 0.53$ \\
\hline \multicolumn{7}{|c|}{ T. weissflogii $\left(4 \times 10^{4}\right.$ cells $\left.\mathrm{ml}^{-1}\right)$ (duration of radioactive feeding) } \\
\hline 10 min feeding & $18.8 \pm 3.2$ & $66.7 \pm 1.5^{*}$ & $29.5 \pm 6.1$ & $0.72 \pm 0.28$ & $0.64 \pm 0.21$ & $1.14 \pm 0.63$ \\
\hline 30 min feeding & $16.2 \pm 4.0$ & $64.1 \pm 3.5^{*}$ & $28.1 \pm 3.6$ & $0.72 \pm 0.22$ & $0.64 \pm 0.13$ & $0.87 \pm 0.36$ \\
\hline 60 min feeding & $20.0 \pm 2.7$ & $70.5 \pm 1.3^{*}$ & $29.9 \pm 3.0$ & $0.68 \pm 0.10$ & $0.63 \pm 0.13$ & $0.61 \pm 0.31$ \\
\hline \multicolumn{7}{|c|}{ 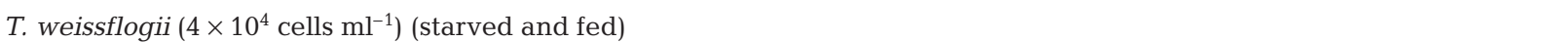 } \\
\hline Starvation & $18.3 \pm 4.4$ & $60.0 \pm 8.4$ & $33.7 \pm 12.3$ & $0.54 \pm 0.51$ & $0.32 \pm 0.12$ & $0.61 \pm 0.35$ \\
\hline Feeding & $22.8 \pm 2.4$ & $68.1 \pm 7.1$ & $31.2 \pm 3.7$ & $0.61 \pm 0.16$ & $0.35 \pm 0.22$ & $0.63 \pm 0.33$ \\
\hline
\end{tabular}


of Se was found in copepods after a radioactive feeding period of $60 \mathrm{~min}$. There was little variation in the AEs of any metal between starved and fed copepods, suggesting that starvation has a negligible influence on the assimilation of these metals. Among the different experiments with $T$. weissflogii as diet (food concentration, duration of radioactive feeding, and starvation), the AEs of metals were quite comparable at the same food concentration $\left(4 \times 10^{4} \mathrm{cells} \mathrm{ml}^{-1}\right)$.

Taking all experiments into consideration (including those with the 2 algal diets), there was a significant correlation between metal $\mathrm{AE}$ and metal distribution in the algal cytoplasm for Cd (Fig. 3), in spite of the higher AE of copepods at the lower food concentration. No relationship was found for Se and Zn however. One likely explanation is that there was no great variation in their cellular distribution among the different treatments. When all 3 metals were considered, a significant relationship between metal AE and metal distribution in the algal cytoplasm was found for copepods feeding on Thalassiosira weissflogii (Fig. 4), suggesting that variation in metal partitioning in the algal cytoplasm was critical for the inter-elemental variation in assimilation.

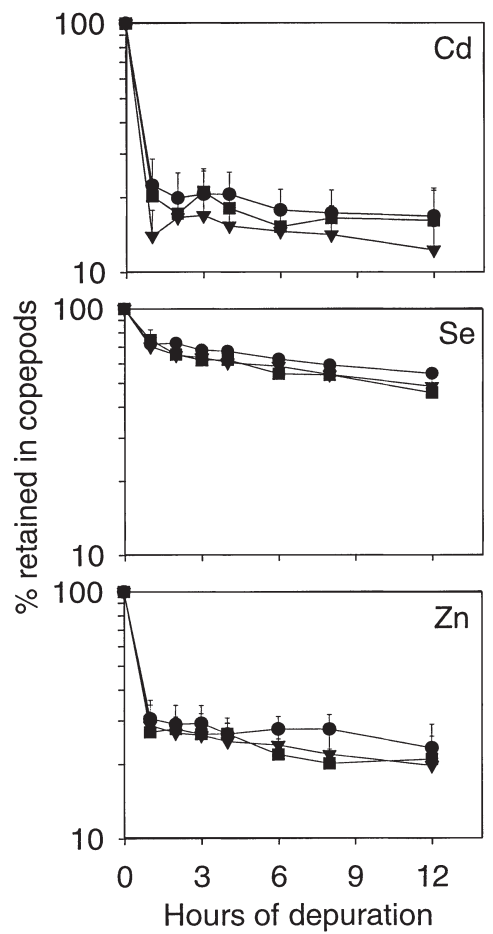

Fig. 2. Calanus sinicus. Retention of $\mathrm{Cd}, \mathrm{Se}$, and $\mathrm{Zn}$ following different durations of radioactive pulse-feeding on the radiolabeled diatom Thalassiosira weissflogii (40000 cells ml ${ }^{-1}$ ). ( 10 min radioactive pulse feeding; $(\boldsymbol{\nabla}) 30$ min radioactive pulse feeding; $(\bullet) 60$ min radioactive pulse-feeding. Data are means $+\mathrm{SD}(\mathrm{n}=6)$

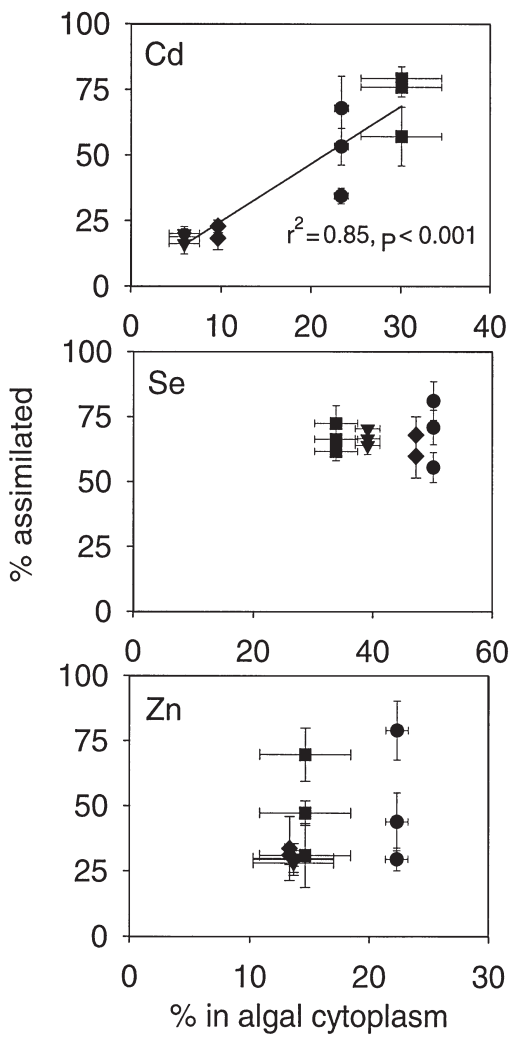

Fig. 3. Calanus sinicus. Relationship between metal assimilation efficiency of the copepod and metal distribution in the algal cytoplasm. (•) Copepods feeding on the diatom Thalassiosira weissflogii at different concentrations; (ם) copepods feeding on the dinoflagellate Prorocentrum minimum at different concentrations; $(\nabla)$ copepods feeding on $T$. weissflogii with different durations of radioactive pulse-feeding; $(\diamond)$ copepods feeding on $T$. weissflogii (starved and fed copepods). Data are means \pm SD ( $n=6$ for metal assimilation efficiency, $\mathrm{n}=2$ for metal distribution in the algal cytoplasm)

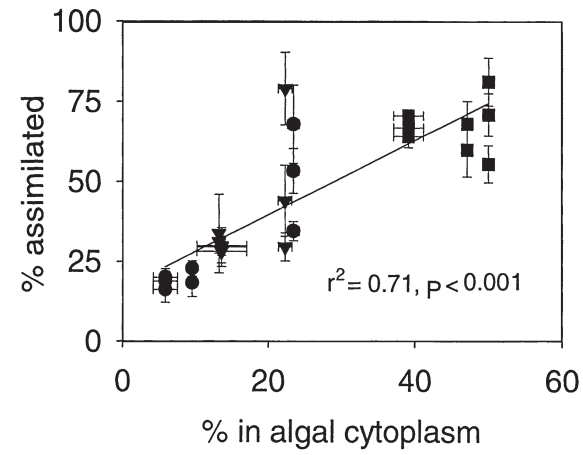

Fig. 4. Calanus sinicus. Relationship between metal assimilation efficiency of the copepod and metal distribution in the cytoplasm of the diatom Thalassiosira weissflogii. (•) $\mathrm{Cd}_{i}(\boldsymbol{\square})$ $\mathrm{Se}_{i}(\boldsymbol{\nabla}) \mathrm{Zn}$. Data are means $\pm \mathrm{SD}(\mathrm{n}=6$ for metal assimilation efficiency, $\mathrm{n}=2$ for metal distribution in the algal cytoplasm) 

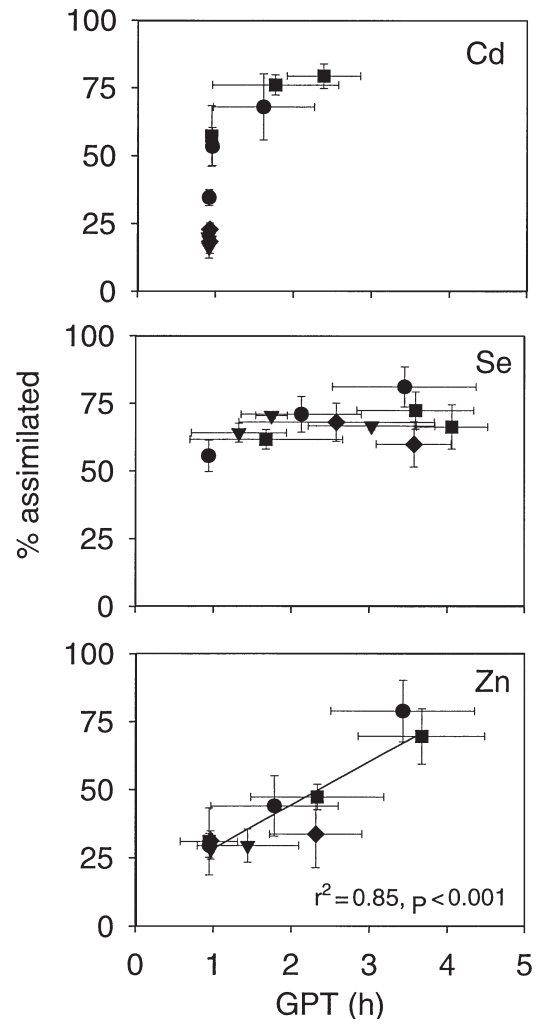

Fig. 5. Calanus sinicus. Relationship between metal assimilation efficiency and gut passage-time (GPT) of metals. (-) Copepods feeding on the diatom Thalassiosira weissflogii at different concentrations; (ם) copepods feeding on the dinoflatellate Prorocentrum minimum at different concentrations; $(\boldsymbol{\nabla})$ copepods feeding on $T$. weissflogii with different durations of radioactive pulse feeding; $(\bullet)$ copepods feeding on T. weissflogii (starved and fed copepods). Data are means $\pm \operatorname{SD}(n=6)$

The GPTs of $\mathrm{Cd}, \mathrm{Se}$, and $\mathrm{Zn}$ in the copepods decreased with increasing food concentration (Table 2). Metal AE appeared to be correlated with GPT (Fig. 5), implying a more efficient assimilation with an increase in metal GPT. A linear relationship between $\mathrm{Zn}, \mathrm{AE}$ and GPT was observed, whereas no apparent relationship was found for Se in our experiments. There was no relationship between GPT and metal distribution in the algal cytoplasm for $\mathrm{Cd}$, Se, or Zn.

\section{Physiological turnover rate of trace metals}

The physiological turnover-rate constant of trace metals was calculated as the slope of the linear regression between the natural log of the percentage of metals retained in the copepods and the time of depuration between 4 and $12 \mathrm{~h}$ (Table 1). No major difference in physiological turnover-rate constant was observed for any of the 3 metals at different food concentrations, or with different radioactive pulse-feeding times, or between the starved and fed copepods. The turnover rate constants were somewhat similar between the 2 algal diets and among the 3 metals, and ranged between 0.32 and $1.15 \mathrm{~d}^{-1}$.

\section{Partitioning of metals between egestion and excretion}

By measurement of the radioactivity of fecal pellets immediately egested by the copepods and of the ambient water, it was possible to separate the relative contribution of metal loss from copepods due to fecal pellet egestion and aqueous excretion (Fig. 6). Within the first hour of depuration, $>75 \%$ of unassimilated $\mathrm{Cd}$ and Zn were found in the feces, with $<25 \%$ of metal lost through excretion. For Se, $>20 \%$ was lost via excretion throughout the depuration period. Differences in food concentration had a marked effect on the relative importance of these 2 processes (Fig. 6). Metal loss through defecation increased substantially with an increase in food concentration. The partitioning of lost metal in fecal pellets and the dissolved state was comparable between Thalassiosira weissflogii and Prorocentrum minimum. With an increase in depuration time, the relative contribution of excretion to metal loss from the copepods also increased, particularly for $P$. minimum, implying that excretion is a dominant pathway for metal loss from the copepods during the physiological turnover period. Excretion was the dominant route for Se loss in copepods feeding at 8000 cells ml $^{-1}$ of the diatom $T$. weissflogii and in copepods feeding at various concentrations of the dinoflagellate $P$. minimum.

Table 2. Calanus sinicus. Gut transit-time of food particles (FPT) and gut passage-time (GPT) of $\mathrm{Cd}, \mathrm{Se}$, and $\mathrm{Zn}$ in copepods feeding on the diatom Thalassiosira weissflogii and the dinoflagellate Prorocentrum minimum at different food concentrations. Values are mean $\pm \mathrm{SD}(\mathrm{n}=6)$

\begin{tabular}{|lcccc|}
\hline Food type & FPT (h) & & GPT (h) \\
& & Cd & Se & Zn \\
\hline T. weissflogii & & & & \\
2000 cells ml & & & \\
8000 cells ml $^{-1}$ & $0.16 \pm 0.05$ & $1.62 \pm 0.65$ & $3.45 \pm 0.92$ & $3.43 \pm 0.92$ \\
40000 cells ml$^{-1}$ & $0.10 \pm 0.01$ & $0.96 \pm 0.02$ & $2.13 \pm 0.77$ & $1.79 \pm 0.82$ \\
$P$. minimum & & & $0.92 \pm 0.01$ & $0.95 \pm 0.01$ \\
2000 cells ml $^{-1}$ & $0.44 \pm 0.11$ & $2.39 \pm 0.47$ & $3.59 \pm 0.75$ & $3.67 \pm 0.81$ \\
8000 cells ml $^{-1}$ & $0.23 \pm 0.03$ & $1.77 \pm 0.81$ & $4.06 \pm 0.46$ & $2.34 \pm 0.85$ \\
40000 cells ml $^{-1}$ & $0.13 \pm 0.03$ & $0.95 \pm 0.01$ & $1.68 \pm 0.98$ & $0.95 \pm 0.37$ \\
\hline
\end{tabular}




\section{Ingestion rate and gut transit-time of food particles}

The ingestion rates of copepods were significantly related to food concentration (Fig. 7). For example, the ingestion rate at the highest food concentration was $8 \times$ (for Thalassiosira weissflogii) and $3.6 \times$ (for Prorocentrum minimum) higher than the ingestion rate measured at the lowest food concentration. No maximum ingestion rate was reached within the food concentrations examined in our study. The measured gut-transit time of food particles (FPT) was inversely related to food concentration, and was similar between the 2 algal diets at the highest food concentration (Table 2). At lower food concentrations, FPT was about $2 \times$ longer in copepods feeding on P. minimum than on $T$. weissflogii. The shortest FPT was $0.1 \mathrm{~h}$, measured at the highest food concentration, whereas the longest FPT was $0.44 \mathrm{~h}$ in copepods feeding on $P$. minimum at the lowest food concentration. Furthermore, the AEs of $\mathrm{Cd}$, Se and $\mathrm{Zn}$ appeared to be correlated with FPT, e.g., AE increased with increasing FPT until it reached a maximum beyond

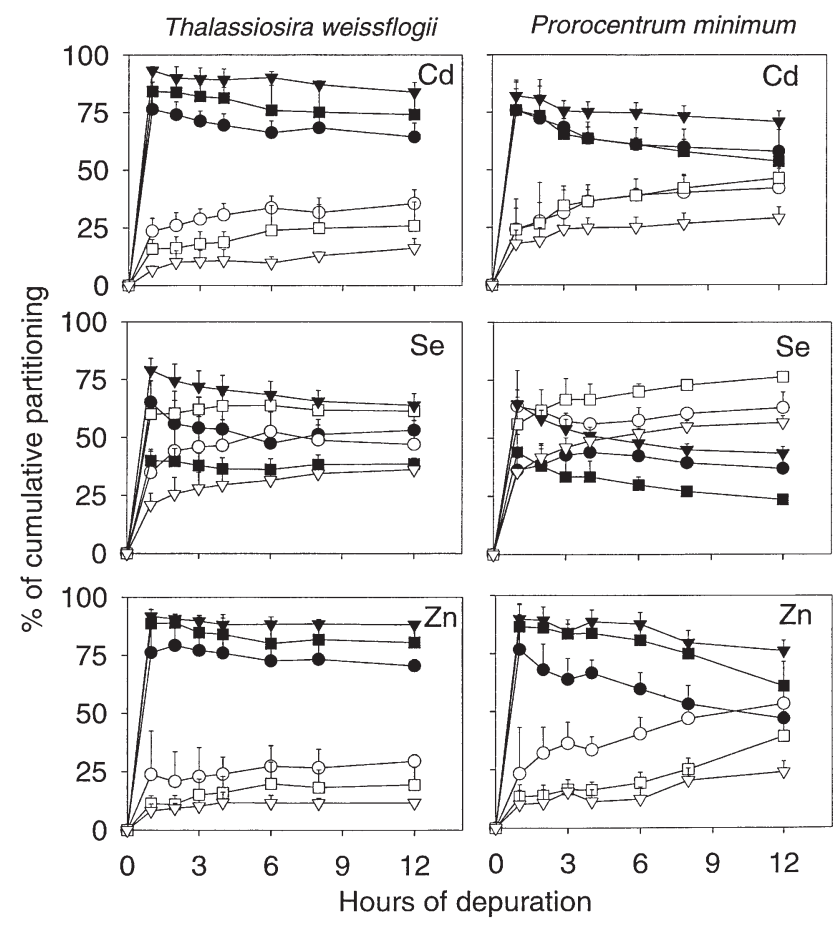

Fig. 6. Calanus sinicus. Cumulative partitioning of metal loss into fecal pellets and dissolved state (excretion) during the depuration period at different food concentrations of the diatom Thalassiosira weissflogii and the dinoflagellate Prorocentrum minimum. At 2000 cells $\mathrm{ml}^{-1}$ : (•) metal in the fecal pellets; (O) metal in the dissolved state; at 8000 cells $\mathrm{ml}^{-1}$ : (口) metal in the fecal pellets; $(\square)$ metal in the dissolved state; at 40000 cells $\mathrm{ml}^{-1}:(\boldsymbol{\nabla})$ metal in the fecal pellets; $(\nabla)$ metal in the dissolved state. Data are means $\pm \operatorname{SD}(n=6)$ which AE was independent of FPT (Fig. 8). The GPT of metals was also positively correlated with the FPT of food particles for both T. weissflogii and P. minimum diets.

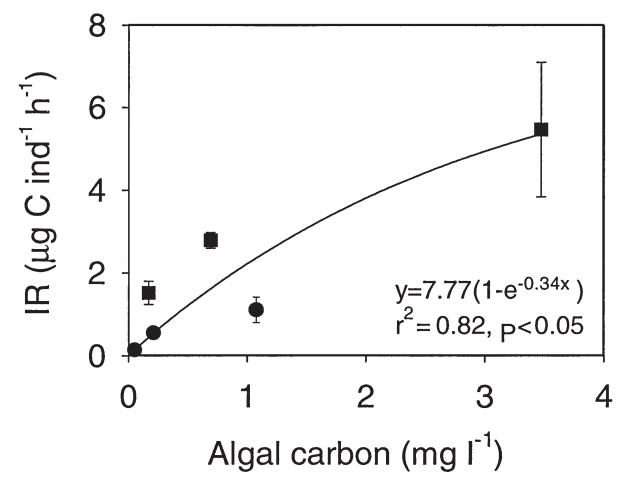

Fig. 7. Calanus sinicus. Ingestion rate $(I R)$ at different food concentrations of the diatom Thalassiosira weissflogii $(\bullet)$ and the dinoflagellate Prorocentrum minimum (ם). Data are means $\pm \mathrm{SD}(\mathrm{n}=6)$

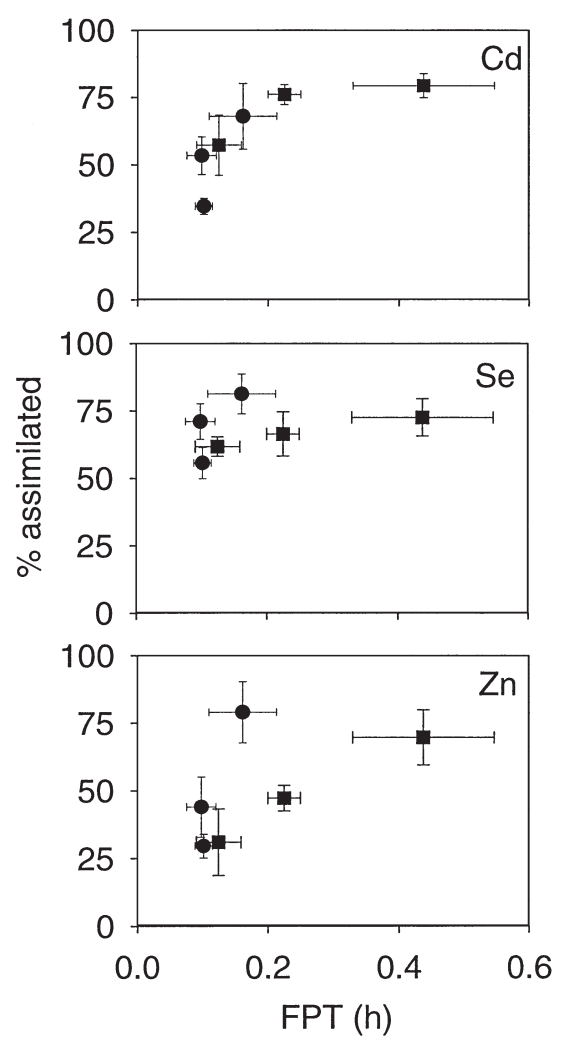

Fig. 8. Calanus sinicus. Relationship of metal assimilation efficiency and the gut transit-time of food particles (FPT). (•) copepods feeding on Thalassiosira weissflogii; (ם) copepods feeding on Prorocentrum minimum. Data are means $\pm \mathrm{SD}(\mathrm{n}=6)$ 


\section{DISCUSSION}

\section{Trace-metal assimilation from ingested food particles}

In previous studies, assimilation efficiencies (AEs) have been measured for copepods as a composite, because of the small size of the individuals used in the experiments (Fisher et al. 1991, Reinfelder \& Fisher 1991, Wang et al. 1996, Wang \& Fisher 1998a). Both short-term (0.5 to $1.0 \mathrm{~h}$ : Wang et al. 1996, Wang \& Fisher 1998a) and long-term (6 to 18 h: Fisher \& Reinfelder 1991, Reinfelder \& Fisher 1991) radioactive feeding were employed to quantify metal AEs. The AEs measured in this study for individual Calanus sinicus were generally comparable to a previous study on another marine copepod, Temora longicornis (Wang \& Fisher 1998a). For example, the AEs of Cd, Se, and Zn were 33 to 53,50 to 59 , and 52 to $64 \%$, respectively, in the copepod T. longicornis feeding on diatoms and phytoplankton assemblage (Wang \& Fisher 1998a), compared with 34 to $57 \%, 56$ to $62 \%$, and 30 to $31 \%$ for $C$. sinicus feeding on diatoms and dinoflagellates at a similar algal biomass in this study. This study also indicated that metal AEs were generally comparable in C. sinicus feeding on the diatom Thalassiosira weissflogii and the dinoflagellate Prorocentrum minimum, suggesting that differences between the 2 algal species had little influence on the metal assimilation of the copepod. Wang \& Fisher (1998a) similarly reported that different algal diets did not appreciably affect metal assimilation in the marine copepod Temora longicornis. However, when T. longicornis fed on Fe oxide particles, the measured metal AEs were about $2 \times$ lower than for individuals feed on phytoplankton (Wang et al. 1996).

In this study, food quantity had a significant effect on metal assimilation by the copepod Calanus sinicus. Thus, a possible physiological influence of metal accumulation may be achieved by feeding copepods at different food densities. In contrast, Wang et al. (1996) found that food concentration (Thalassiosira pseudonana, ranging from 0.016 to $0.8 \mathrm{mg} \mathrm{C} \mathrm{l}^{-1}$ ) had little effect on the assimilation of $\mathrm{Cd}$ and Se by the neritic copepods Acartia tonsa and Temora longicornis. The assimilation of $\mathrm{Zn}$ by these copepods was however reduced from 70 to $50 \%$ by an increase in food concentration from 0.016 to $0.8 \mathrm{mg} \mathrm{Cl}^{-1}$. The present work also indicated that $\mathrm{AE}$ of $\mathrm{Zn}$ in $C$. sinicus was most affected by a change in food concentration. The AE of Zn decreased from 79 to $30 \%$ in copepods feeding on Thalassiosira weissflogii when food concentration increased from 0.054 to $1.076 \mathrm{mg} \mathrm{Cl}^{-1}$, and decreased from 70 to $31 \%$ in copepods feeding on Prorocentrum minimum when food concentration increased from
0.174 to $3.470 \mathrm{mg} \mathrm{C}^{-1}$. For $\mathrm{Se}$, the food concentration of $P$. minimum did not influence its assimilation by $C$. sinicus. The influence of food concentration on metal assimilation in copepods therefore appears to be metal-specific and food-specific. Different variables such as ingestion activity, metal passage-time and gut transit-time of food particles may all be responsible for the underlying effects of food concentration on metal assimilation. Conflicting results have also been obtained on the influence of food concentration on C assimilation in marine copepods. Conover (1966) showed that $\mathrm{C}$ assimilation by $C$. hyperboreus was relatively constant (about $70 \%$ ) over a food concentration range of 0.1 to $2.4 \mathrm{mg} \mathrm{C} \mathrm{l}^{-1}$. A few later studies have also indicated that food concentration has little influence on carbon assimilation in copepods feeding on different food particles (Abou Debs 1984, Wang et al. 1996). As significant influence of food concentration on carbon assimilation was however found by Gaudy (1974) and Landry et al. (1984). For example, the C assimilation of the copepod C. pacificus decreased from 85 to $68 \%$ and N assimilation from 92 to $74 \%$ when the algal concentration ( $T$. weissflogii) increased from $10^{3}$ cells ml ${ }^{-1}$ to $8 \times 10^{3}$ cells ml ${ }^{-1}$.

In this study, the gut-transit time of food particles (FPT) was found to be significantly dependent on food concentration, in contrast to an earlier study by Ellis \& Small (1989), who found that the gut-evacuation rate of Calanus marshallae was not dependent on food concentration (Thalassiosira weissflogii, ranging from 500 to 4000 cells ml-1). The FPT estimated for C. sinicus was $<0.44 \mathrm{~h}$, consistent with the estimation by Dam \& Peterson (1988) for Temora longicornis based on the relationship between FPT and temperature. The FPT in marine copepods is, however, species-specific, ranging from $0.3 \mathrm{~h}$ to $>2 \mathrm{~h}$, as measured by gut fluorescence or radiotracer techniques (Kiørboe et al. 1982). In the present study, the difference in FPT accounted at least partially for the variation in metal $\mathrm{AE}_{\text {; }}$ thus, longer retention of food particles in the copepod's gut resulted in more efficient metal assimilation.

Very few studies have distinguished the gut transittime of food particles (FPT, defined as the first appearance of fecal pellets) and the gut passage-time of metals (GPT, defined as the time of recovery of $90 \%$ of unassimilated cumulative feces) in marine copepods. Wang \& Fisher (1998a) estimated that the GPT of metals in the copepod Temora longicornis was 4 to $15 \mathrm{~h}$, compared to an FPT of $<0.5 \mathrm{~h}$ for food (Dam \& Peterson 1988). Consistent with this, our study indicated that the FPT was shorter than the GPT of metals in Calanus sinicus ( 1 to $4 \mathrm{~h}$ for all 3 metals). The longer residence time of metals in the copepod's gut implies that metal digestion may be decoupled from food digestion as a result of a more complicated chemical digestion (e.g., 
desorption, extracellular digestion and mixing of the gut contents). Metal AEs in C. sinicus were correlated with the GPT of the metals, indicating that the differences in metal AEs were also partially attributable to the differences in the metal's residence time in the copepod's gut. Similar results have also been observed for marine bivalves in which metal AE increased with increasing metal GPT as a result of more efficient assimilation (e.g., intracellular digestion) when the metal was retained longer in the digestive tract (Wang \& Fisher 1996, Roditi \& Fisher 1999, Chong \& Wang 2000).

Metal partitioning in algal cytoplasm has been consistently implied to have a crucial effect on metal assimilation in marine copepods and other herbivores (Reinfelder \& Fisher 1991, Wang \& Fisher 1996, 1999). Reinfelder \& Fisher (1991) suggested that zooplankton characterized by a short gut residence-time ( $<30 \mathrm{~min})$ probably employed a 'liquid' digestive strategy in which only the soluble form of metals was bioavailable and easily assimilated. Cell-wall and membranebound metals were enriched in fecal pellets and rapidly exported out of the surface waters (Fisher \& Reinfelder 1995). Thus, the subcellular distribution of trace elements may largely determine whether they are assimilated or exported with sinking biogenic particles (Hutchins et al. 1995). There was, however, limited evidence to demonstrate that for a specific metal its assimilation is directly affected by metal distribution in the algal cytoplasm (Hutchins et al. 1995). In the present study, significant correlation was only found for $\mathrm{Cd}$ between its $\mathrm{AE}$ and distribution in the algal cytoplasm, although metal partitioning in the diatom's cytoplasm appeared to account for the variations in metal assimilation among the 3 metals. Furthermore, a significant difference in metal AEs was documented in copepods feeding at different food concentrations, even though the metal cytoplasmic distribution was constant among the different food concentration treatments. Differences in metal partitioning in algal cytoplasm, while critical to explaining the inter-elemental variation of AE (Reinfelder \& Fisher 1991, 1994), may therefore not be responsible for the variation in AEs of Se and $\mathrm{Zn}$ in copepods in response to different food environments. The feeding physiology of the copepods such as the GPT of metals and the FPT of food may also account for $\mathrm{AE}$ variation under diverse food conditions.

In copepods, metal accumulation from ingested particles is determined by metal $\mathrm{AE}$, metal concentration of the food particles, metal efflux rate, and the copepod's ingestion rate (Wang et al. 1996). Food concentration can directly affect all 4 of these physiological and geochemical parameters. A pronounced variation in a copepod's feeding rate was noted for various algal diets and at different food concentrations. In our study, the ingestion rate of copepods on the dinoflagellate Prorocentrum minimum was somewhat higher than copepods feeding on the diatom Thalassiosira weissflogii, and increases with an increase in food density. Other experimental studies have established that ingestion rate generally increases with increasing phytoplankton abundance and algal cell size (Paffenhöfer 1984, Cowles et al. 1988). The observed relationship between the ingestion/absorption rate and food concentration may be attributable to the adaptation of digestive enzymes, such that the copepods can modify their rates of digestion by varying the amount and activity of digestive enzyme at different food levels (Abou Debs 1984). It is likely that the decrease in metal AE with increasing food concentration may potentially maintain the amount of metal taken up by the copepods, whereas the copepod's ingestion rate will increase with increasing food concentration.

\section{Regeneration of trace metals}

Biologically-mediated regeneration is critical to metal cycling in marine and freshwater systems (Hutchins et al. 1993, Hutchins \& Bruland 1994, Twiss \& Campbell 1995, Twiss et al. 1996, Wang \& Fisher 1998b). The present results have demonstrated that the physiological turnover of assimilated trace metals in Calanus sinicus is relatively independent of algal diet or the amount of food ingested, similar to the results of previous studies on other copepods (Wang et al. 1996). However, the excretion rate of metals measured over a longer depuration period (d) increased with increasing food density (Wang \& Fisher 1998b). The relative importance of different routes of metal regeneration (egestion as packed fecal pellets and excretion into the dissolved state) can considerably affect the fate and distribution of metals in the water column. Although previous studies have considered the partitioning of ingested metals in different compartments, namely copepods, dissolved state, and feces (Hutchins et al. 1995, Wang et al. 1996), this study has provided the first realistic kinetic budget for ingested metals in copepods, egested feces, and excretion, by carefully recovering the egested feces at frequent time intervals. Hutchins et al. (1995) demonstrated the importance of $\mathrm{Fe}$ regeneration by marine copepods, e.g., about $50 \%$ of ingested Fe was partitioned into the dissolved state and $25 \%$ each of ingested $\mathrm{Fe}$ was partitioned into the copepods and fecal pellets after $4 \mathrm{~h}$ depuration. Wang et al. (1996) found that a significant fraction of $\mathrm{Am}, \mathrm{Co}$, Se and $\mathrm{Zn}$ was recovered in the water after $4 \mathrm{~h}$ depuration, with metals in the fecal pellets accounting only for a minor fraction. Because a relatively high density of grazers 
was used in these previous studies (0.5 to 1.0 individuals $\mathrm{ml}^{-1}$ ), it is possible that metals associated with the egested fecal pellets may have been desorbed and contributed to the metals in the dissolved state (Fisher et al. 1991, Lee \& Fisher 1992).

In our study, egested fecal pellets were measured for each individual copepod, and were removed immediately after they had been produced; thus, the potential desorption of metals from the fecal pellets was kept to a minimum. In addition, in our experiment comparing metal AEs with different durations of pulse radioactive feeding (10 to $60 \mathrm{~min}$ ), the ingestion rate was calculated as the sum of the radioactivity in the copepods and the radioactivity in the egested feces collected during the radioactive feeding period. The production of radioactive feces increased with the duration of radioactive feeding (with a typical copepod gut-transit time of $<10 \mathrm{~min}$ at the food concentration employed). Because we did not find any significant difference in metal AEs with different durations of radioactive feeding (except for Se), it was unlikely that the egested metals were desorbed into the dissolved state within the time frame of feces collection. Consequently, our estimation of the relative importance of egestion versus excretion in the overall metal loss from copepods may be a true reflection of these 2 processes.

Although our calculations indicated that egestion represents a major pathway by which unassimilated $\mathrm{Cd}$ and $\mathrm{Zn}$ are returned to the ambient environment, excretion may be a dominant route by which assimilated and incorporated metals are regenerated into the dissolved state (Wang \& Fisher 1998b). Similar to earlier studies (Wang et al. 1996, Wang \& Fisher 1998a), there was very little radioactivity detected in the egested feces after $6 \mathrm{~h}$ depuration in non-radioactive waters, indicating that excretion dominated the loss of assimilated metals. Recent studies have demonstrated that the physiological turnover rate in marine copepods is exceedingly high ( 0.3 to $\left.2.6 \mathrm{~d}^{-1}\right)$, and thus can contribute markedly to the dissolved metal pool in the water column (Wang \& Fisher 1998a,b, Xu et al. 2001). The present study also indicated that the route of metal regeneration is metal-specific, and is presumably affected by different algal diets and food concentration. The relative significance of egestion increases with increasing food concentration, as a result of inefficient assimilation by the copepods. Hutchins \& Bruland (1994) suggested that an abundance of prey can lead to a less efficient assimilation of ingested nutrients (i.e., gluttonous feeding), resulting in a greater degree of incorporation of partially digested materials into fecal pellets and a possibly higher remineralization rate.

Differences in food concentration may also affect the fate of metals realeased into the water column by graz- ing copepods. A lower food concentration results in a higher metal AE, and a decrease in metal loss by egestion, thus effectively reducing metal export by sinking fecal pellets. In our study, we also found that fecal pellets were smaller at lower food concentrations, similar to observations by Dagg \& Walser (1986). Because the sinking rate of fecal pellets is highly dependent on their size, smaller pellets may be retained longer in the surface waters, further increasing the potential of metal cycling into the dissolved state. Conversely, larger pellets produced at higher food concentrations, coupled with a higher rate of metal loss by egestion, may facilitate the export of metals to deeper waters. The production of fecal pellets in coastal surface waters is generally high (e.g., $3 \times 10^{5}$ total pellets $\mathrm{m}^{-2}$ $\mathrm{d}^{-1}$ in the Northeast Pacific: Knauer et al. 1979). Coupled with the relatively high concentration of metals in freshly produced feces (Krishnaswami et al. 1985), fecal pellets can play an important role in transporting metals to deeper waters, and may contribute to the removal of metals from surface waters and possibly the enrichment of the deeper waters or sediments. The amount of resorption of metals from sinking pellets remains unknown. Furthermore, fecal pellets containing unassimilated metals and other nutrients may serve as an important food source for bacteria, protozoans, or benthic animals (Bulter \& Dam 1994), especially in areas below the photic zone (Urrere \& Knauer 1981).

In summary, our study has demonstrated that metal assimilation in the marine copepod Calanus sinicus is significantly affected by food concentration, but not by difference in radioactive pulse-feeding time and starvation. Metal AEs determined for the 2 algal diets (diatom Thalassiosira weissflogii and dinoflagellate Prorocentrum minimum) were generally comparable. Extrapolation of these laboratory results to field conditions using a mixture of algal foods remains to be studied. The distribution of metals in the algal cytoplasm may be important in accounting for the variability of $\mathrm{Cd}$ assimilation in copepods observed in different batches of experiments and between the 2 algal diets. Dependence of the metal AEs on the gut transit time of food materials and gut passage-time of metals suggests that the gut physiology is another critical parameter in determining metal AEs under diverse food conditions. It is also likely that the acidic gut environment may affect metal assimilation in marine copepods (Xu et al. 2001). The physiological turnover rate of trace metals was relatively independent of the amount of food ingested and the species of alga used as food. The routes of metal loss in copepods (egestion and excretion) were metal-specific and strongly affected by algal diet species and food concentration. For $\mathrm{Cd}$ and $\mathrm{Zn}$, egestion by fecal pellets was the major route 
for the loss of unassimilated metals, whereas both excretion and egestion were equally important for the loss of unassimilated Se from the copepods. Excretion into the dissolved state was nevertheless the dominant pathway for the loss of assimilated metals in the copepod. The relative importance of different routes of metal depuration from copepods may be important to our understanding of the fate of metals in surface waters.

Acknowledgements. We are grateful to the anonymous reviewers for their detailed and constructive comments on this work. This study was supported by a Competitive Earmarked Research Grant of the Hong Kong Research Grant Council (HKUST 6137/99M) to W.-X.W.

\section{LITERATURE CITED}

Abou Debs C (1984) Carbon and nitrogen budget of the calanoid copepod Temora stylifera: effect of concentration and composition of food. Mar Ecol Prog Ser 15:213-223

Bulter M, Dam HG (1994) Production rates and characteristics of fecal pellets of the copepods Acartia tonsa under simulated phytoplankton bloom conditions: implications for vertical fluxes. Mar Ecol Prog Ser 114:81-91

Chong K, Wang WX (2000) Assimilation of cadmium, chromium, and zinc by the green mussel Perna viridis and the clam Ruditapes philippinarum. Environ Toxicol Chem 19: 1660-1667

Conover RJ (1966) Factors affecting the assimilation of organic matter by zooplankton and the question of superfluous feeding. Limnol Oceanogr 11:346-354

Cowles TJ, Olson RJ, Chisholm SW (1988) Food selection by copepods: discrimination on the basis of food quality. Mar Biol 100:41-49

Dagg MJ, Walser WE Jr (1986) The effect of food concentration on fecal pellet size in marine copepods. Limnol Oceanogr 31:1066-1071

Dam HG, Peterson WT (1988) The effect of temperature on the gut clearance rate constant of planktonic copepods. J Exp Mar Biol Ecol 123:1-14

Decho AW, Luoma SN (1991) Time-courses in the retention of food material in the bivalves Potamocorbula amurensis and Macoma balthica: significance to the absorption of carbon and chromium. Mar Ecol Prog Ser 78:303-314

Ellis SG, Small LF (1989) Comparison of gut-evacuation rates of feeding and non-feeding Calanus marshallae. Mar Biol 103:175-181

Fisher NS, Reinfelder JR (1991) Assimilation of selenium in the marine copepod Acartia tonsa studied with a radiotracer ratio method. Mar Ecol Prog Ser 70:157-164

Fisher NS, Reinfelder JR (1995) The trophic transfer of metals in marine systems. In: Turner DR, Tessier A (eds) Metal speciation and bioavailability in aquatic systems. Wiley, Chichester, p 363-406

Fisher NS, Burns KS, Cherry RD, Heyraud M (1983) Accumulation and cellular distribution of ${ }^{241} \mathrm{Am},{ }^{210} \mathrm{Po}$, and ${ }^{210} \mathrm{~Pb}$ in two marine algae. Mar Ecol Prog Ser 11:233-237

Fisher NS, Nolan CV, Fowler SW (1991) Assimilation of metals in marine copepods and its biogeochemical implications. Mar Ecol Prog Ser 71:37-43

Fowler SW, Knauer GA (1986) Role of large particles in the transport of elements and organic compounds trough the oceanic water column. Prog Oceanogr 16:147-194
Gaudy R (1974) Feeding of four species of pelagic copepods under different experimental conditions. Mar Biol 25: 125-141

Guillard RRL, Ryther JH (1962) Studies of marine planktonic diatoms. 1. Cyclotella nana Hustedt and Detonula confervacea (Cleve) Gran. Can J Microbiol 8:229-239

Hutchins DA, Bruland KW (1994) Grazer-mediated regeneration and assimilation of $\mathrm{Fe}, \mathrm{Zn}$ and $\mathrm{Mn}$ from planktonic prey. Mar Ecol Prog Ser 110:259-269

Hutchins DA, DiTullio GR, Bruland KW (1993) Iron and regenerated production: evidence for biological iron recycling in two marine environments. Limnol Oceanogr 38: $1242-1255$

Hutchins DA, Wang WX, Fisher NS (1995) Copepod grazing and the biogeochemical fate of diatom iron. Limnol Oceanogr 40:989-994

Knauer GA, Martin JH, Bruland KW (1979) Fluxes of particulate carbon, nitrogen and phosphorus in the upper water column of the northeast Pacific. Deep-Sea Res 26:97-108

Kiørboe T, Møhlenberg F, Nicolajsen H (1982) Ingestion rate and gut clearance in the planktonic copepod Centropages hamatus in relation to food concentration and temperature. Ophelia 21:181-194

Kiørboe T, Møhlenberg F, Hamburger K (1985) Bioenergetics of the planktonic copepod Acartia tonsa: relation between feeding, egg production and respiration, and composition of specific dynamic action. Mar Ecol Prog Ser 26:85-97

Krishnaswami S, Baskaran M, Fowler SW, Heyraud M (1985) Comparative role of salps and other zooplankton in the cycling and transport of selected elements and natural radionuclides in Mediterranean waters. Biogeochemistry $1: 353-360$

Landry MR, Hassett RP, Fagerness V, Downs J, Lorenzen CL (1984) Effect of food acclimation on assimilation efficiency of Calanus pacificus. Limnol Oceanogr 29:361-364

Lee BG, Fisher NS (1992) Decomposition and elemental release from zooplankton debris. Mar Ecol Prog Ser 88: $117-128$

Lee BG, Fisher NS (1994) Effects of sinking and zooplankton grazing on the release of elements from planktonic debris. Mar Ecol Prog Ser 110:271-281

Omori M, Ikeda T (1992) Methods in marine zooplankton ecology. Krieger, Malabar, FL

Paffenhöfer GA (1984) Food ingestion by the marine planktonic copepod Paracalanus in relation to abundance and size distribution of food. Mar Biol 80:323-333

Reinfelder JR, Fisher NS (1991) The assimilation of elements ingested by marine copepods. Science 251:794-796

Reinfelder JR, Fisher NS (1994) The assimilation of elements ingested by marine planktonic bivalve larvae. Limnol Oceanogr 39:12-20

Reinfelder JR, Fisher NS, Fowler SW, Teyssie JL (1993) Release rates of trace elements and protein from decomposing planktonic debris. 2. Copepod carcasses and sediment trap particulate matter. J Mar Res 51:423-442

Roditi HA, Fisher NS (1999) Rates and routes of trace element uptake in zebra mussels. Limnol Oceanogr 44:1730-1749

Schmidt MA, Zhang YH, Hutchins DA (1999) Assimilation of Fe and carbon by marine copepods from Fe-limited and Fe-replete diatom prey. J Plankton Res 21:1753-1764

Twiss MR, Campbell PGC (1995) Regeneration of trace metals from picoplankton by nanoflagellate grazing. Limnol Oceanogr 40:1418-1429

Twiss MR, Campbell PGC, Auclair JC (1996) Regeneration, recycling, and trophic transfer of trace metals by microbial food web organisms in the pelagic surface waters of Lake Erie. Limnol Oceanogr 41:1425-1437 
Urrere MA, Knauer GA (1981) Zooplankton fecal pellet fluxes and vertical transport of particulate organic material in the pelagic environment. J Plankton Res 3:369-387

Wang WX, Fisher NS (1996) Assimilation of trace elements and carbon by the mussel Mytilus edulis: effects of algal food composition. Limnol Oceanogr 41:197-207

Wang WX, Fisher NS (1998a) Accumulation of trace elements in a marine copepod. Limnol Oceanogr 43:273-283

Wang WX, Fisher NS (1998b) Excretion of trace elements by marine copepods and their bioavailability to diatoms. J Mar Res 56:713-729

Wang WX, Fisher NS (1999) Assimilation efficiencies of chemical contaminants in aquatic invertebrates: a synthesis. Environ Toxicol Chem 18:2034-2045

Editorial responsibility: Otto Kinne (Editor),

Oldendorf/Luhe, Germany
Wang WX, Fisher NS, Louma SN (1995) Assimilation of trace elements ingested by the mussel Mytilus edulis: effects of algal food abundance. Mar Ecol Prog Ser 129:165-176

Wang WX, Reinfelder JR, Lee BG, Fisher NS (1996) Assimilation and regeneration of trace elements by marine copepods. Limnol Oceanogr 41:70-81

Whitfield M, Turner D (1987) The role of particles in regulating the composition of seawater. In: Stumm W (ed) Aquatic surface chemistry: chemical processes at the particlewater interface. Wiley, New York, p 457-493

Xu Y, Wang WX, Hsieh DPH (2001) Influence of metal concentration in phytoplankton and seawater on metal assimilation and regeneration in marine copepods. Environ Toxicol Chem 20:1067-1077

Submitted: August 2000; Accepted: November 8, 2000 Proofs received from author(s): July 18, 2001 